\title{
Water Minimisation at Kriel Power Station Using Process Integration
}

\author{
D. Mokhonoana, G Gerick and F Waanders
}

\begin{abstract}
The primary objective of this study is to determine the possible reduction of the raw water intake of an existing power station by applying process integration techniques to optimise the use of water available within the system. The secondary objective is to reduce the waste water produced within the process, hence reducing the cost of water, reducing the amount of chemicals and reducing the energy needed to treat water. This will be achieved by considering the power plant system as a whole (i.e. integrated or holistic approach) in order to improve its design and/or operation which exploit the interactions between different units. This paper will describe the process that was followed to determine the suitability of process integration at Kriel Power Station.
\end{abstract}

Keywords—process integration, minimisation, sinks, sources.

\section{INTRODUCTION}

Water and energy are the basic needs for human existence, and due to population and industrial growth the need for both will continue to increase. As energy costs increase, the intersection between energy and water becomes important as the main primary resources for power generation are water and coal.

South Africa's power base is comprised mainly of coal fired generation. Eskom power stations supply about $95 \%$ of South Africa's electricity and more than half of the electricity used on the African continent [1]. The extensive use of coal to generate electricity is projected to continue for many years. Eskom uses approximately $2 \%$ of the country's total water consumption annually [2].

During the 2015/2016 financial year, Eskom used approximately 313 billion litres of water for electricity generation, mainly at its coal-fired power stations [2]. Water use targets, in terms of litres per unit of electricity sent out, are set for each power station every year. The objective is to bring Eskom's water consumption relative to power produced to 1.3 litres a kilowatt-hour by 2022 [3] Eskom recognised that the organisation would have to find ways of limiting increases in water consumption and contribute to sustainable water use in South Africa. Eskom is thus committed and determined to support the drive to improve the management of South Africa's scarce water resources. Water Minimisation Approaches at

Dorian Mokhonoana is Master Student, North West University, South Africa (corresponding author’s e-mail: MokhonD@eskom.co.z ).

G Gericke with North West University, South Africa.

Frans Waanders is with the School of Chemical and Minerals Engineering of the North West University, Bult area-Potchefstroom-South Africa.

\section{Kriel Power Station}

The power station consists of six once through boilers and steam turbines each generating a maximum of $600 \mathrm{MW}$ of energy. Kriel Power Station receives raw water from the Vaal and Usutu water schemes for various uses. . The freshwater intake is about $110 \mathrm{ML} / \mathrm{d}$. Raw water is used in the plant processes such as cooling tower makeup, condenser makeup, and slurry preparation makeup, ash handling makeup, syngas humidification, quench system makeup, and demineralised water. The water balance model and diagram for Kriel Power Station with specified process water volumes and quality standards for the various unit operations is included in table 1 . A process flow diagram of water flow at the power station was developed (Fig 1).

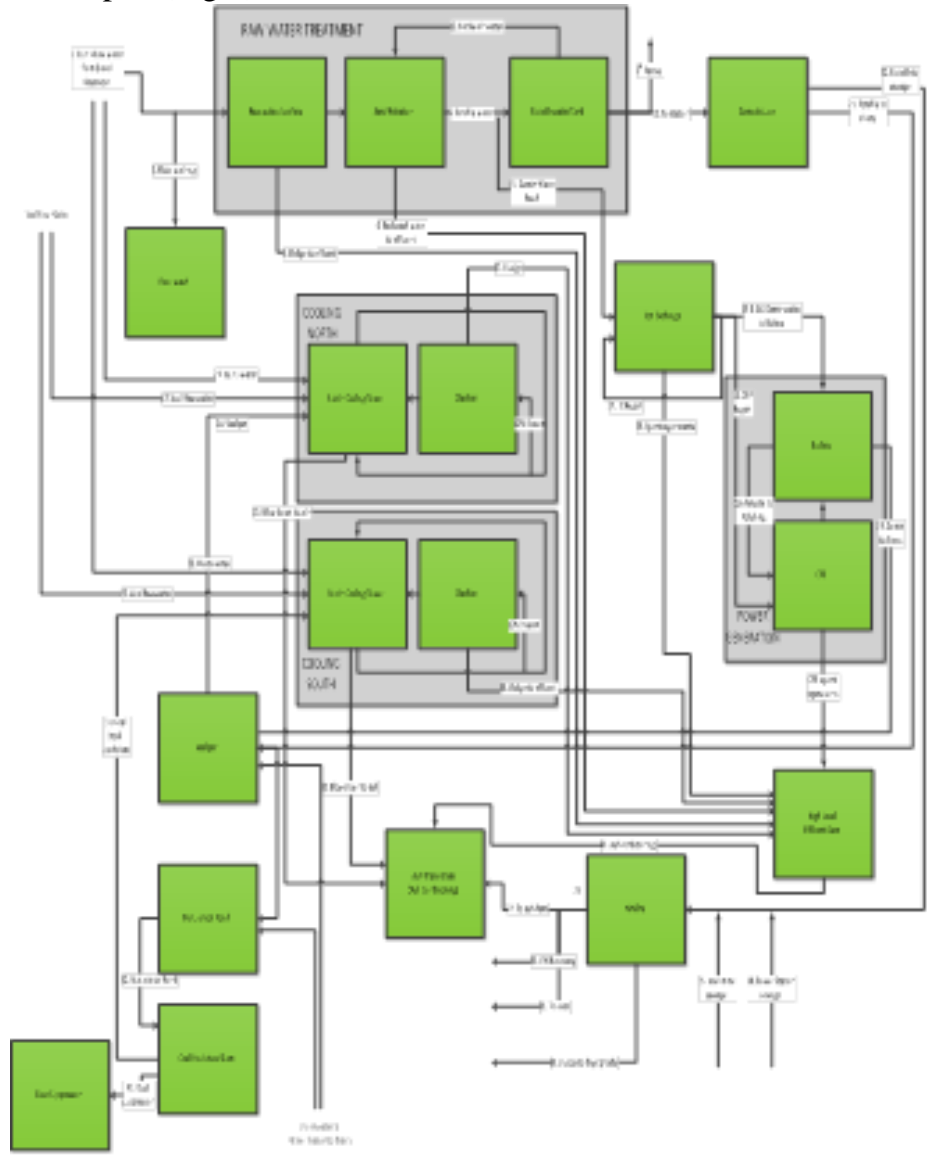

Fig 1: Block diagram of water network at Kriel Power Station [4] 


\section{INTRODUCTION OF PROCESS INTEGRATION PRINCIPLES}

Process Integration is a systematic technique used to identify, allocate, analyse and optimize a water network system for reducing freshwater consumption and minimize wastewater generation. Since its introduction by Wang and Smith (1994) [5], this technique has been one of the most widely used tools for conservation of water in industrial processes. There are three main water recovery schemes adopted in process integration [5] which are: re-use, recycle and regeneration.

Process integration techniques for water minimisation are initiated by identifying the water sources and water sinks of the network followed by matching appropriate sources and sinks as water quality allows. The water network therefore first has to be compiled and flow and quality data can subsequently be allocated to process units within the network.

For a single contaminant network a graphical approach can be used to obtain the optimum water network. For multiple contaminants, a mathematical programming approach is used as the graphical approach becomes tedious and inaccurate. The mathematical programming approach of water networks is based on the optimisation of a network superstructure. The superstructure of a water network is a description of all possible feasible connections between water using processes and water treating processes. The optimal solution is a subset of the superstructure and is identified by the use of optimisation methods. Based on this superstructure, a mathematical model, describing the problem with all economic, geographical, control and safety constraints included, is built. This enables the technique to deal with more detailed design considerations such as data uncertainties, lifecycle impacts, network topology and capital costs [6]. The optimisation problem represented as a mathematical model is then solved using rigorous algorithms to obtain global or nearglobal solutions. Minimum water targets are determined simultaneously with the network design. GAMS software is used to develop the process integration model. GAMS is specifically designed for modelling linear, nonlinear and mixed integer optimisation problems [7]. The system's inherent solvers allow a user to solve complex problems with a simple and very flexible setup.

\section{APPLYING THE PROCESS INTEGRATION PRINCIPLES TO KRIEL POWER STATION}

The flow rate, total dissolved solids concentration and the conductivity of the various streams of the Kriel power station are tabulated in Table 1. This data was used to design the superstructure for the water system (Fig 2)

TABLE: 1: STREAM DESCRIPTION

\begin{tabular}{|c|c|c|c|c|}
\hline \multirow{2}{*}{\begin{tabular}{|l|} 
Stream No \\
\end{tabular}} & \multirow[b]{2}{*}{ Stream description } & \multirow{2}{*}{\begin{tabular}{|c|} 
Flow rate \\
(m3/d) \\
\end{tabular}} & \multicolumn{2}{|c|}{ Stream quality } \\
\hline & & & TDS (mg/l) & Conductivity (uS/cm) \\
\hline 1 & Usutu Raw water from Davel Reservoir & 14749 & 43 & 68.1 \\
\hline 2 & Floor washing (Fire-hydrants) & 2203 & 43 & 68.1 \\
\hline 3 & Raw water clarifier sludge to effluent & 444 & 61 & 95 \\
\hline 4 & Dirty backwash water to drains & 444 & 48 & 75 \\
\hline 5 & Filtered water & 14305 & 45 & 70.4 \\
\hline \multirow{6}{*}{$6-9,11$} & Water 3rd parties & & 45 & 70.4 \\
\hline & \begin{tabular}{|l|} 
Water to Kriel town \\
\end{tabular} & & 45 & 70.4 \\
\hline & Water to Kriel mine and NW Shaft & & 45 & 70.4 \\
\hline & Water to contractors & & 45 & 70.4 \\
\hline & Water to kwanala centre & & 45 & 70.4 \\
\hline & 3rd parties & 3000 & 45 & 70.4 \\
\hline 10 & Clean filter backwash water & 444 & 45 & 70.4 \\
\hline 12 & Potable to Power Station & 3000 & 45 & 70.4 \\
\hline 13 & Demin water feed & 7862 & 45 & 70.4 \\
\hline 14 & Demineralized water production & 7506 & 0 & 0.07 \\
\hline 15 & Demineralized water to Power Station & 6824 & 0 & 0.07 \\
\hline 16 & Water to CPP regeneration & 682 & 0 & 0.07 \\
\hline 17 & Deminiralized water to regeneration & 682 & 0 & 0.07 \\
\hline 18 & HP Demineralized to Power Station by pump & 0 & 0 & 0.07 \\
\hline 19 & Demin water to station drains & 3412 & 0 & 0.07 \\
\hline 20 & Potable water to Sewage plant & 300 & 255 & 400 \\
\hline 21 & Potable water to Station drains & 1890 & 58 & 91 \\
\hline 22 & Vaal raw water supply & 92778 & 130 & 204 \\
\hline 23 & Usutu Raw water to north cooling system & 0 & 45 & 70.4 \\
\hline 24 & Recovered water from Vaalpan & 800 & 732 & 1150 \\
\hline 25 & Recovered sewage effluent & 1216 & 249 & 391 \\
\hline 26 & North cooling tower blow down & 3177 & 2548 & 4000 \\
\hline 27 & North cooling tower clarifier sludge & 714 & 2548 & 4000 \\
\hline 28 & Spent regenerants to effluent system & 1039 & 127 & 200 \\
\hline 29 & Usutu raw water to south cooling system & 0 & 45 & 70.4 \\
\hline 30 & Recovered water from the maturation pond & 0 & 567 & 890 \\
\hline 31 & Recovered water fron coal stock yard & 0 & 510 & 800 \\
\hline 32 & South cooling tower blow down & 6467 & 2548 & 4000 \\
\hline 33 & South cooling tower clarifier sludge & 627 & 2548 & 4000 \\
\hline 34 & Sewage from the Power Station & 300 & 255 & 400 \\
\hline 35 & Sewage from the Kriel mine & 1350 & 255 & 400 \\
\hline 36 & Sewage effluent for use in cooling & 0 & 249 & 391 \\
\hline 37 & Sewage effluent to ash dams & 0 & 249 & 391 \\
\hline 38 & Sewage effluent to the environment & 0 & 249 & 391 \\
\hline 39 & Sewage sludge to drying beds & 50 & 249 & 391 \\
\hline 40 & Ash conditioning & 1400 & 6369 & 10000 \\
\hline 41 & Dust suppression & 400 & 2548 & 4000 \\
\hline
\end{tabular}




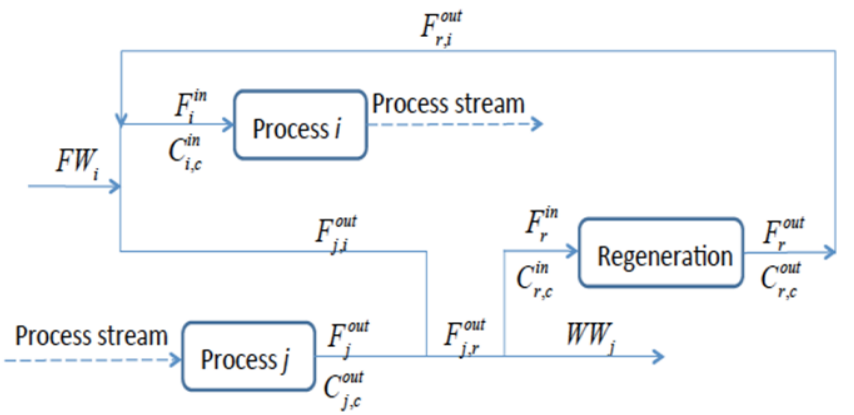

Fig 2: Superstructure for the mathematical model

\section{WATER USING OPERATIONS CONSTRAINTS}

A limit on water quality used during wastewater minimisation through mathematical optimisation is called a constraint. Constraint (1) states that the total flow rate into sink i comprises the freshwater flow rate plus the total flow from all the relevant sources and the flow from the regenerator (a process that removes contaminant from a water stream to allow for further use). In its current form, this constraint assumes a single regenerator. Constraint (2) states that the outlet stream from source $\mathrm{j}$ is made up of wastewater that is dispensed with as effluent, the overall reuse stream from source $j$ to all the relevant sinks, as well as the water stream into the regenerator. Constraint (3) states that the total load of contaminant $\mathrm{c}$ into sink i cannot exceed the maximum allowed load of the same contaminant in the sink. Lastly, constraint (4) is a feasibility constraint that ensures that all the flow rates in the final design are within allowable limits.

$$
\begin{aligned}
F_{i}^{\text {in }} & =F W_{i}+\sum_{j \in J} F_{j, i}^{\text {out }}+F_{r, i}^{\text {out }}, \forall i \in I=\{i \mid i=\operatorname{sink}\} \\
F_{j}^{\text {out }} & =W W_{j}+\sum_{i \in I} F_{j, i}^{\text {out }}+F_{j, r}^{\text {out }}, \forall j \in J=\{j \mid j=\operatorname{source}\}
\end{aligned}
$$

$$
\begin{gathered}
C_{i, c}^{i n} \geq \frac{\sum_{j \in J} F_{j, i}^{\text {out }} C_{j, c}^{\text {out }}}{F_{i}^{\text {in }}} \quad \forall i \in I=\{i \mid i=\operatorname{sink}\} \\
, c \in C=\{c \mid c=\text { contaminant }\}
\end{gathered}
$$

$\delta y_{j, i} \leq F_{j, i}^{\text {out }} \leq F_{j}^{\text {out }, U} y_{j, i}$

$\forall i \in I=\{i \mid i=\operatorname{sink}\}, j \in J=\{j \mid j=$ source $\}$

\section{V.OBJECTIVE FUNCTION}

The objective function is the functional property to be optimised (minimised or maximized). The objective function focussing on the minimization of the total freshwater intake into the facility is given in constraint (5a). It may also include the amount of wastewater generated as in (5b) or minimize the costs associated with intake of freshwater and treatment of wastewater as in $(5 c)$

$$
\begin{aligned}
& \text { Min } F W=\sum_{i \in I} F W_{i} \\
& \text { Min } F W, W W=\sum_{i \in I} F W_{i}+\sum_{j \in J} W W_{j} \\
& \text { Min Cost }=\sum_{i \in I} F W_{i} \times \operatorname{Cost} F W+\sum_{j \in J} W W_{j} \times \text { TreatmentCost } W W
\end{aligned}
$$

All three objective functions were used to minimize the respective variables. This eventually will enable power station management to make decisions from both a water use target and cost point of view.

\section{RESULTS AND DISCUSSION}

Flow data used in the model was taken from the Saltman model (Saltman is a software used by Eskom power station for salt and water balance within the water process) provided by Kriel Power Station. The freshwater intake of 109730 m3/day predicted by the Saltman model compares well to the current 110 to $115 \mathrm{Ml} / \mathrm{d}$ water usage reported by the power station. A separate model was compiled, which optimizes the water utilisation network without the regenerator being used.

Three different objective functions were set (given by equations $5 \mathrm{a}-\mathrm{c}$ ) to minimize freshwater intake, freshwater and wastewater combined or costs associated with water intake and treatment respectively. Each of these targets provided

\begin{tabular}{|c|c|c|c|}
\hline Unit Operations & Sources & Sinks & Variables \\
\hline Usutu Raw Water & & & $\mathrm{X}$ \\
\hline Vaal raw water supply & & & $\mathrm{X}$ \\
\hline Floor Washing & & $\mathrm{X}$ & \\
\hline 3rd parties & & $\mathrm{X}$ & \\
\hline Sand filter backwash water & & $\mathrm{X}$ & \\
\hline Dirty Sand filter backwash water & $\mathrm{X}$ & & \\
\hline $\begin{array}{l}\text { Power station potable water use } \\
\text { (bathrooms, kitchen, etc.) }\end{array}$ & & $\mathrm{X}$ & \\
\hline $\begin{array}{l}\text { Power station potable water } \\
\text { leaking into drains }\end{array}$ & $\mathrm{X}$ & & \\
\hline Power Generation: Demin Water & & $\mathrm{X}$ & \\
\hline $\begin{array}{l}\text { Power Generation: Demin Water } \\
\text { to drains-mostly tank overflows }\end{array}$ & $\mathrm{X}$ & & \\
\hline $\begin{array}{l}\text { Power Generation: CPP spent } \\
\text { regenerates }\end{array}$ & $\mathrm{X}$ & & \\
\hline Ion Exchange: Spent regenerates & $\mathrm{X}$ & & \\
\hline Effluent Dam & $\mathrm{X}$ & & \\
\hline North Cooling Tower & $\mathrm{X}$ & $\mathrm{X}$ & \\
\hline South Cooling Tower & $\mathrm{X}$ & $\mathrm{X}$ & \\
\hline WWTW & $\mathrm{X}$ & & \\
\hline Ash Dam/Ash conditioning & & $\mathrm{X}$ & \\
\hline Dust suppression & & $\mathrm{X}$ & \\
\hline $\begin{array}{l}\text { Vaalpan - mostly from leaks } \\
\text { from process units }\end{array}$ & $\mathrm{X}$ & & \\
\hline
\end{tabular}
unique networks and different targets to work towards by the power station management, whether it is in order to reach the minimum freshwater intake, to minimize waste production or endeavouring to minimize costs associated with water usage and waste management.

TABLE II: SOURCES AND SINKS

After formulating the initial model with sources and sinks as listed in Table 2, it was apparent that certain modelling 
outcomes could contribute to more effective water management, but may not necessarily be implemented without further investment or certain commitments by power station management.

The outcomes from this study can be summarised as follows:

(i) Re-use of wastewater treatment plant effluent can be used as make up to cooling tower.

(ii) With the two cooling towers operating at different cycles of concentration (CoC), the blow down water of the South Cooling Tower (operated at lower $\mathrm{CoC}$ ) is of an acceptable quality to feed into the North Cooling ITower

(iii) Water from other sources e.g. regenerates can be used for floor washing operations

\section{CONCLUSIONS \& RECOMMENDATIONS}

The following conclusions can be made from the findings in this document:

- Savings of between $4 \%$ and $13 \%$ may be possible by changing the way water is currently utilised and re-used at the station. These figures translate to $1 /$ uso values of 2.23 to 2.04 respectively. These savings still do not achieve the design water consumption target of 1.8 1/uso. The same objective function values are achieved by minimizing freshwater consumption or the sum of freshwater consumption and wastewater produced.

- Reuse of the wastewater treatment plant effluent has a direct impact on water consumption and investment in infrastructure to enable the introduction of good quality sewage effluent into the cooling towers shows savings in the order of R 2.2 million per year.

- Optimisation of the stations water network still brings $3 \%$ savings without implementation of any of the three preliminary findings mentioned.

- Observations on site showed a significant amount of water that end up in the station drains. With the bulk of water use at the station going to the cooling towers it is expected that regardless if any other of the findings of this study is implemented, effective maintenance on cooling cycle equipment (such as valves, ejector weirs etc.) may reduce water consumption by as much as $5 \%$ or R 1 million/month. Findings in this report are based on input water demands (for respective unit process) that include prevailing leaks at the station. Any savings through maintenance is additional to the results already shown in this report.

- Management of the cooling cycle and especially blow down water with related procedures have a significant impact on the amount of freshwater intake. A thorough understanding of the intricacies of cooling tower operation and performance is critical to optimise this. The appointment of a task team to perform this work approximates savings of R1.5 Million per month after initial investment of an estimated R360 000 and it is highly recommended design water consumption target of 1.8 1/uso. The same objective function values are achieved by minimizing freshwater consumption or the sum of freshwater consumption and wastewater produced.

- Reuse of the wastewater treatment plant effluent has a direct impact on water consumption and investment in infrastructure to enable the introduction of good quality sewage effluent into the cooling towers shows savings in the order of R 2.2 million per year.

- Optimisation of the stations water network still brings $3 \%$ savings without implementation of any of the three preliminary findings mentioned.

- Observations on site showed a significant amount of water that end up in the station drains. With the bulk of water use at the station going to the cooling towers it is expected that regardless if any other of the findings of this study is implemented, effective maintenance on cooling cycle equipment (such as valves, ejector weirs etc.) may reduce water consumption by as much as $5 \%$ or R1 million/month. Findings in this report are based on input water demands (for respective unit process) that include prevailing leaks at the station. Any savings through maintenance is additional to the results already shown in this report.

- Management of the cooling cycle and especially blow down water with related procedures have a significant impact on the amount of freshwater intake. A thorough understanding of the intricacies of cooling tower operation and performance is critical to optimise this. The appointment of a task team to perform this work approximates savings of R1.5 Million per month after initial investment of an estimated R360 000 and it is highly recommended.

\section{APPENDIX}

\section{Sets}

$I=\{i \mid i=$ water using operation $(\sin \mathrm{k})\}$

$J=\{j \mid j=$ water generating operation (source) $\}$

$C=\{c \mid c=$ contaminant $\}$

$R=\{r \mid r=$ regenerator $\}$

\section{Continuous variables}

$F W_{i}=$ freshwater into sink $i$

$W W_{j}=$ wastewater stream from source $j$

$F_{r}^{i n}=$ inlet water stream into regenerator $r$

$F_{r}^{\text {out }}=$ outlet water stream from regenerator $r$

$F_{r, i}^{o u t}=$ recycle water stream from regenerator $r$ to sink $i$

$C_{r, c}^{i n}=$ inlet concentration of contaminant $c$ into regenerator $r$

$C_{r, c}^{\text {out }}=$ outlet concentration of contaminant $c$ from regenerator $r$

Binary variable

$y_{i, j}=\left\{\begin{array}{l}1 \leftarrow \text { if a stream exists between units } i \text { and } j \\ 0 \leftarrow \text { otherwise }\end{array}\right.$

\section{Parameters}


$C_{j, c}^{o u t}=$ outlet concentration of contaminant $c$ from source $j$

$C_{i, c}^{i n}=$ inlet concentration of contaminant $c$ into sink $i$

$R R_{r, c}=$ removal ratio for contaminant $c$ in regenerator $r$ $F_{j}^{\text {out }, U}=$ maximum outlet flowrate from source $j$

\section{ACKNOWLEDGMENT}

I thank my creator God who guided and sustained me to accomplish this study. My sincere gratitude and acknowledgement goes to my supervisor Professor F.Waanders and my co-supervisor Gerhard Gericke for valuable guidance, constructive criticism, continuous support of my Msc study, for their patience, motivation, and immense knowledge and inspiring encouragement. Their guidance helped me in all the time of research and writing of this paper and dissertation. I could not have imagined having a better supervisor and co-supervisor for my Msc study. Many thanks go to Eskom my employer who have invested the company's resources in achieving the goal.

\section{REFERENCES}

[1] https://www.dwa.gov.za/io/Docs/CMA/CMA\%20GB\%20Training\%20 Manuals/gbtrainingmanu alchapter1.pdf

[2] http://nepadwatercoe.org/wp-content/uploads/Strategic-Overview-ofthe-Water-Sector-in-South-Africa-2013.pdf

[3] http://www.iol.co.za/business/companies/eskom-to-cut-water-use-by260bn-litres-1.1326359\#.U6rGOE1DGss [y] June 252012 at 05:00am

[4] Kriel Operating Manual 114463/12096/11957

[5] Wang, Y. P. \& Smith, R., 1994a. Wastewater Minimisation. Chemical Engineering Science, 49(7), pp. 981-1006.

[6] Tan, R. R., Ng, D. K. S., Foo, D. C. Y. \& Aviso, K. B., 2009. A superstructure model for the synthesis of single-contaminant water networks with partitioning regenerators. Process Safety and Environmental Protection, Volume 87, pp. 197-205

[7] www.gams.com, March 2014

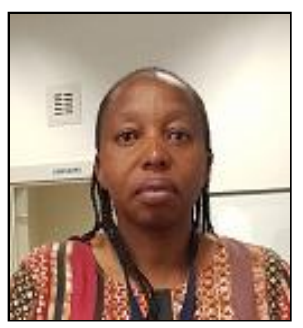

Dorian Mokhonoana obtained her diploma in Chemical Engineering at Witwatersrand Technikon University of Johannesburg), she then pursued her studies and obtained a B-Tech Degree from Pretoria Technikon. After that she studied with the University of Pretoria were she is obtained her Bsc Honors in Applied Science. She worked for the Department of Labour in Johannesburg as an Occupational Health and Safety Inspector from 1996 to 2000. From 2001 she joined Eskom in Generation at Lethabo power station as a Systems Engineer, working at boiler plant department until 2006, from there she moved to Eskom Research as an Engineer and concentration on water projects. She is involved in various projects which involve water minimization, optimization of antiscalant, clean in place and membrane optimization.

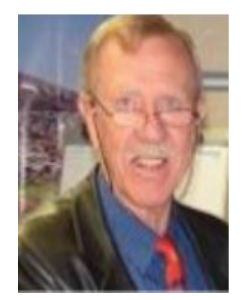

Prof. Waanders obtained his Bsc Degree in Physics and Geology, M.sc and Dsc degree in Nuclear Physics at the PU for CHE. From 1976 until 1979 he was a geologist at the Buffelsfontein Gold Mine before returning to the University. From1979 until 1989 he lectured in the department of Physics at the PU for CHE, but during 1986 - 1987 and 1998 he was a guest lecturer/researcher at the Munster University, Germany. In 1990 he joined the Geology Department at the PU for CHE. In 1992 he was asked to join the
Metallurgical Engineering Department and completed his engineering studies to be able to register as professional engineer and in 1997 the Metallurgical Engineering Department was incorporated in the school of Chemical and Mineral Engineering where he is currently a professor and the director of the school.

$\mathrm{He}$ has delivered numerous papers on various topics at national and international conferences and is the author/co-author of more than 150 publications of international standards and he was part of the 3-man team that inscribed the Vredefort Dome as World Heritage Site in 2005.

Prof. Waanders is a member of the South Africa Institute of Physics, South Africa Institute of Mining and Metallurgy and a fellow member of the Geology Society of South Africa. He is a registered engineer and natural scientist. He is married to Petro, private practicing dietician.

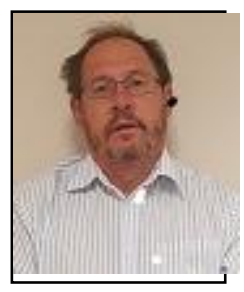

Gerhard Gericke obtained his Diploma in Analytical Chemistry from Witwatersrand Technikon in 1984, he then continued with his studies at the University of the Western Cape were he completed Msc in 2002. He started working at Eskom from 1982, he has in various projects, and he has become has become a specialist in the following chemistry disciples Water and Applied Chemistry, Environmental Chemistry, Fuel cell technology, Water treatment technologies and Aqueous Natural Organic matter. He has presented, provided training and written various publications in conferences and workshops. 